\title{
Implementation of Project-Based Learning in EduNet PC WORX IEC 61131-3 Based PLC Training Program
}

\author{
Budi Mulyanti $^{\text {a,1, }}$, Arjuni B. Pantjawati ${ }^{\text {a,2 }}$, Siscka Elvyanti ${ }^{\text {a,3 }}$, Erik Haritman ${ }^{\text {a,4 }}$ \\ ${ }^{a}$ Department of Electrical Engineering Education, Universitas Pendidikan Indonesia (UPI) \\ J1. Dr. Setiabudhi No. 207, Bandung, 40154 Indonesia \\ 1b_mulyanti@yahoo.com, 2arjunib@yahoo.com, 33iscka_elvyanti@yahoo.com
}

\begin{abstract}
In this paper, the implementation of project-based learning (PBL) in EduNet PC Worx IEC 61131-based PLC (programmable logic control) training program is described and discussed. By using PBL, the students are expected to understand the concept and have ability to accomplish projects in a good level of training objectives. The observation results show that the trainee can demonstrate the academic knowledge and have ability to solve the problem in borderline level. Meanwhile, the ability to organize a work schedule, to complete work on time and correctly, to work under pressure, to utilize equipment and training module correctly, and to handle equipment safely sometimes do not meet expectations. However in the softskill aspects such as attendance, attitude to job and supervision, and ability to work in a team frequently meet satisfactory level. Paper will be sum up with some recommendations for solving the obtained shortcomings.
\end{abstract}

Index Terms - project-based learning, EduNet PC Worx IEC 6113, programmable logic control

\section{Introduction}

As the most popolous province in Indonesia, West Java has a lot of problems related to human resources besides natural resources and others. This very large population, namely 43 million according to 2010 population census, is expected to be the nation's assets. This expectation can be achieved through the human resources-oriented development such as expanding productive employment, improvement of the quality of food and nutrition as well as improvement of education quality [1].

Since 2005, the Indonesian government has launched a policy related to the number of high school students, namely by reversing the current share of high school students, from 30 percent general to 70 percent vocational, by 2015 [2]. In fact, several authors emphasize the importance of vocational education in developing job-related skills to help employment in specific occupations [3] [4]. By the new policy, the government, aiming to reduce high unemployment rates among educated youth.

In West Java there are 1984 vocational school and 123 of them are located in the city of Bandung. Most of the vocational school in Bandung, namely107 are private, which managed by foundation or community .

Vocational graduates are expected to have competencies and skills in accordance with their study program. In fact, most of the vocational graduates work in the fields that are not relevant to their expertise which indicates that their vocational skills do not meet the standards demanded by the industry.
In general, public vocational schools have a better quality than the private school. This is because the quality of learning process and school's facilities of public vocational school are the responsibility of the Government, school board and school partners. Meanwhile for private vocational school, the learning process and school's facilities only depend on the participation of parents, and school's owner (foundation). Unfortunety, the participation of parents can not be well expected due to their low economic level.

SMK Kartika XIX and SMK Bandung Selatan 1 can be considered to represent the problems faced by the private vocational school in Bandung. Based on the data obtained from both the schools, nearly $80 \%$ of students have low class economic background. With very limited school facilities and low parent participation, it is difficult to obtain high-quality graduates from the both schools.

Power Installation Engineering is one of the program that is available both in schools. From the data obtained from both schools, it appears that the number students of Power Installation is relatively low compared to other skills programs. The data of students based on skill program of 2012/2013 academic year can be seen in Table 1 [Profile of SMK Kartika XIX Bandung] and Table 2 [Profile of SMK Bandung Selatan 1]

Table 1. Data of SMK Kartika XIX students based on skill program of 2012/2013 academic year

\begin{tabular}{clccc}
\hline \multirow{2}{*}{ No. } & \multirow{2}{*}{ Skill Program } & \multicolumn{3}{c}{ Total of students } \\
\cline { 2 - 5 } 1. & Mechanical engineering & 50 & 0 & 50 \\
2. & Power Installation Engineering & 38 & 0 & 38 \\
3. & light vehicles Engineering & 66 & 2 & 68 \\
4. & Motorcycle Engineering & 61 & 0 & 61 \\
5. & Computer Engineering and & 96 & 11 & 107 \\
& Networks & & & \\
\hline
\end{tabular}

Table 2. Data of SMK Bandung Selatan I students based on skill program of 2012/2013 academic year

\begin{tabular}{clccc}
\multirow{2}{*}{ No. } & \multicolumn{1}{|}{ Skill Program } & \multicolumn{3}{c}{ Total of students } \\
\cline { 3 - 5 } & & male & female & Total \\
\hline 1. & Power Installation Engineering & 28 & 0 & 28 \\
2. & Audio Video Engineering & 25 & 0 & 25 \\
3. & Mechanical Engineering & 49 & 0 & 49 \\
4. & Otomotif Engineering & 97 & 0 & 97 \\
5. & Motorcycle Engineering & 85 & 0 & 85 \\
6. & Computer Engineering and & 137 & 21 & 158 \\
& Network & & & \\
\hline
\end{tabular}

The lack of students willingness to choose Power Installation Program was caused by the lack of industry 
demand to the graduates of this program. Based on preliminary data through informal interviews to the industry, the lack of the demand due to the low quality of graduates. And this low quality may be caused by the elimination of some subjects in both schools. One of the the subject is PLC competence.

Meanwhile, PLC competence is one of subject given in Department of Electrical Enginering Education. The PC WORX IEC 61131 software and the supporting hardware owned by the Department were obtained from EduNet Company, Germany. With the wider utility of the equipment, the EduNet provide will provide free assistance in software training (workshops).

Project-based learning (PBL) combines traditional subject-matter objectives and goals with an authentic learning environment. The main reason for using authentic activities as a model is the increased understanding that develops through application and manipulation of knowledge within context. Finding a solution to the problem is posed by the teacher or the new social environment, are more likely to develop the generic and subject specific skills when using a project-based curriculum [5]. Therefore in our community service, PBL was used as a learning method to develop students competencies on PLC especially by learning PC Worx software using IELC 130 starter kit. In this paper, the difficulties of private vocational students in the learning process of PLC, particularly in the simulation of automation using PC Worx IEC 61131 software using PBL method, will be discussed. The qualitative method was used in this research.

\section{Methodology \\ Method of Learning}

PBL was used as a learning method in the whole activities conducted in 2 (two) days of coomunity services in the Laboratory of Industrial Electronics, Department of Electrical Engineering Education, UPI, Bandung. One teacher acted as a facilitator as well as a manager of the learning program. In facilitator mode, the teacher works with students to frame relevant and meaningful questions and to present logical arguments, guides students in seeking answers and researching, structures knowledge-building tasks, coaches' necessary social skills, and assesses student progress. As manager, the teacher directs small groups and independent work experiences [6].

The students of this study were 20 eleventh to twelfth graders, from 2 privates' vocational school in Bandung. All students were separated into 6 (six) small, collaborative groups. Each group was guided by one well trained -teacher assistant. The duty of each group was to find sources, conduct research, and responsible for learning and the completion of tasks.

The subject matter provided to the students are General basics of PLC and PLC Programming for Phoenix Contact (basic) for the first day. While for the second day, students were offered subject matter of PLC Programming for Phoenix Contact (intermediate) and Wireless PLC Programming. Meanwhile the media used during the learning process are: PC WORX software, ILC 130 Starter Kit, LAN network, LCD Projector, and learning module.

\section{Method of Assesment}

Assessing the students' performance in a PBL consideration of various assessment techniques, were both the content and the authentic assessment for evaluates students over time throughout their learning, whereas exams assess students at the end of the course [7]. The categories of authentic assessments generally, are: (1) performance assessment, (2) portfolio assessment, (3) reflection, and (4) self-assessment [8]. However, in this research using selfassessment as evaluate method. The self-assessment refers to reports students' evaluation of their own performance with reasonable justifications.

The self-assessment sheets in the form of questionnaire were distributed to all students in the first day as well as in the second day. This assesment used Likert scale in the range of 1 to 5, representing highly agree, agree, in doubt, disagree and highly disagree, respectively. The instrument for assesment is shown in Table 3 .

Table 3 Assesments sheet

\begin{tabular}{|c|l|l|l|l|c|c|}
\hline No & \multicolumn{1}{|c|}{ Aspects } & 1 & 2 & 3 & 4 & 5 \\
\hline 1 & $\begin{array}{l}\text { Difficulty in understanding the } \\
\text { theory }\end{array}$ & & & & & \\
\hline 2 & $\begin{array}{l}\text { The difficulty in solving the } \\
\text { problem }\end{array}$ & & & & & \\
\hline 3 & $\begin{array}{l}\text { Difficulty in completing tasks } \\
\text { correctly and on time }\end{array}$ & & & & & \\
\hline 4 & $\begin{array}{l}\text { Difficulty in completing tasks } \\
\text { under pressure }\end{array}$ & & & & & \\
\hline 5 & $\begin{array}{l}\text { The difficulty in using } \\
\text { equipment and learning } \\
\text { modules }\end{array}$ & & & & & \\
\hline 6 & $\begin{array}{l}\text { Difficulty in operating the } \\
\text { equipment by taking into } \\
\text { account the safety factor }\end{array}$ & & & & & \\
\hline 7 & $\begin{array}{l}\text { Difficulty in attending the } \\
\text { program }\end{array}$ & & & & & \\
\hline 8 & Difficulty in working in team & & & & & \\
\hline
\end{tabular}

\section{Module Overview}

The IEC 61131-3 is the first real endeavor to standardize programming languages for industrial automation. The standard programming is split by two views as common elements and programming languages [9].

\section{Common Elements}

Within the common elements, the data types, variable and configuration are defined. Data typing prevents errors in an early stage. It is used to define the type of any parameter used. This avoids for instance dividing a date by an integer. Based on these, one can define own personal data types, known as derived data types.

Variables are only assigned to explicit hardware addresses (e.g. input and output) in configurations, resources, or programs. In this way a high level of hardware independency is created, supporting the reusability of the software. The scopes of the variables are normally limited to the organization unit in which they are declared, e.g. local. If the variable should have global scope, they have to be declared as such (VAR_GLOBAL). Parameters can be 
assigned an initial value at start up and cold restart, in order to have the right setting.

To understand these better at the highest level (figure 1) [10], the entire software required to solve a particular control problem can be formulated as a: (1) configuration is specific to a particular type of control system, including the arrangement of the hardware, processing resources, memory addresses and system capabilities; (2) resources is a processing facility that is able to execute IEC programs; (3) tasks control the execution of a set of programs and/or function blocks; (4) programs are built from a number of different software elements written in any of the IEC defined language; and (5) functions and function blocks are the basic building blocks, containing a data structure and an algorithm. Functions and function blocks, which are able to exchange data.

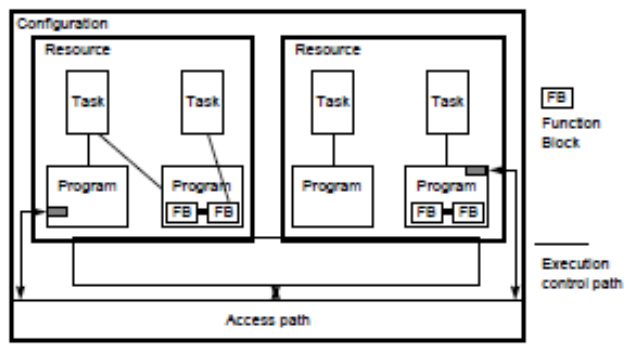

Fig. 1. Configuration software model

\section{Understanding the Programming language}

Within the standard four programming languages are defined. This means that their syntax and semantics have been defined, leaving no room for dialects. The languages consist of two textual and three graphical versions. The textual versions are: 1) Instruction List (IL) is its European counterpart. As textual language, it resembles assembler; and 2) Structured Text (ST) is a very powerful high-level language with its roots in Ada, Pascal, and C. It contains all essential elements of a modern programming language. Then, the graphical versions are: 1) Ladder Diagram (LD) has its roots in the USA. It is based on the graphical presentation of relay ladder logic; 2) Function Block Diagram (FBD) is very common to process industry. It expresses the behavior of functions, function blocks and programs as a set of interconnected graphical blocks, like in electronic circuit diagrams; and 3) Sequential Function Chart (SFC) structures the internal organization of a program, and helps to decompose a control problem into manageable parts, while maintaining the overview.

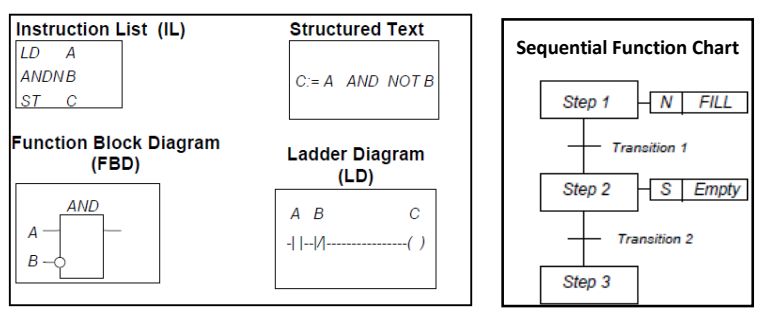

Fig. 2. The five IEC 61131-3 programming languages

In figure 2, all five languages describe the simple program part. The choice of programming language is dependent on four aspects: the programmers' background, the problem at hand, the level of describing the problem, the structure of the control system, and the interface to other people/departments.

All four languages are interlinked; they provide a common suite, with a link to existing experience. In this way, they also provide a communication tool, combining people of different backgrounds.

\section{Students Feedback}

Student feedback was obtained at the end of the first day and the second day of the course using single way, all participant were given assessment sheet. From 20 students, only 14 students who completed questionnaires.

Students were asked to answer questions 1-8 with Likert Scale with choice responses ( $1=$ highly agree, 2 = agree, $3=$ in doubt, $4=$ disagree, and $5=$ highly disagree) and also asked the comment. In general, the students' feedback was very positive. For example, one of the students summarized his experience in PLC course in PBL as follows.

The responses to the questionnaires, shown in figure 4 , centered around the disagree rating, with a learning toward outstanding. Students' responses are aggregated across class and time - such that the resulting bar graph shows total number of students, for each day and each question, broken out by students' response. For example, of the students who responded to question \#4, about difficulty in completing tasks under pressure, in first day, 10 students answered "disagree" and 3 students rated the difficulty in completing tasks under pressure as "agree". However in second day, the responses have little change. This is shows in figure 4, that is response for question \#4, 8 students answered "disagree" and 4 students become "in doubt" for the answer. This means that the PLC course from first day to second day more complex and students have more difficulties.

The result on difficulty in understanding the theory as question \#1 in the first day, seven 7 student (35.7\%) cited a theme of "agree". Examples went from the general "it was difficult enough" and become more easily in second day was shows 8 students $(57 \%)$ cited a theme of "disagree". Of the 14 comments on difficulty in solving the problem as question \#2, 6 students (43\%) in first day, and 7 students $(35.7 \%)$ in the second day cited theme "disagree". This result was positive but not significant confirmed the use of the method as a major contributing factor in the improved results.

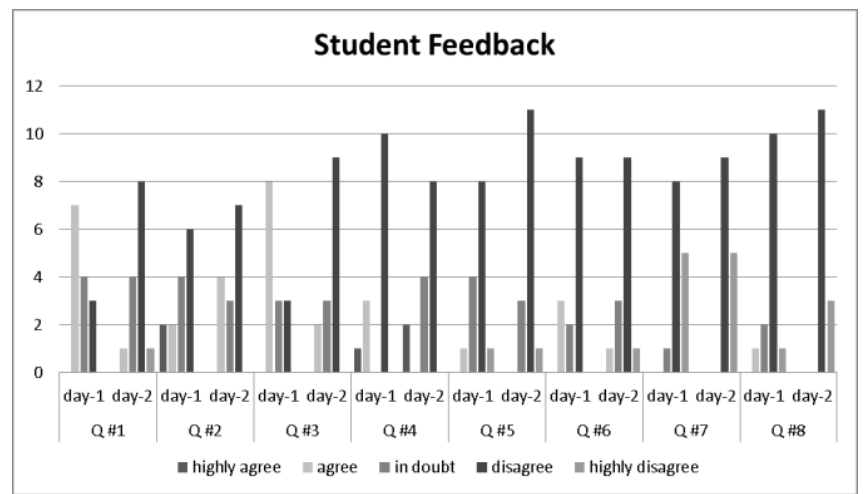

Fig. 4. Student feedback to questionnaire

The authors thought it valuable to see what impact the project-based learning course had on students after their 
learning. A second-day self-assessment was used to gain information on the ability of the case study to promote collaboration. On question "difficulty in working on team (question \#8)" students reported a significantly higher disagreement rating when compared with the first-day selfassessment.

It was hypothesized that this case study would promote higher-order thinking skills. On the second-day selfassessment, a greater proportion of students in the secondday reported, without prompting, usage of higher-order thinking skills such as understanding the theory, problem solving, completing task with correctly and ability to use the equipment when compared the first-day self-assessment.

\section{Conclusions}

In general, the students showed difficulties in all aspects in the first day of training. In the second day, some students were able to overcome the difficulties, especially in understanding the theory, completing the project correctly and on time, attending the training, and working in group.

The data demonstrated that this case study leads to increase learning gains of learning as measured by content and skills-based self-assessment to a second-day. Questionnaire results reported that second-day selfassessment not only reported usage of higher-order thinking skills such as problem solving and data analysis but also demonstrated these skills on a second-day self-assessment to a significantly greater degree relative to first-day selfassessment results.

Taken together, this investigation supports the hypothesizes that PBL is an effective approach for students to learn PLC in relevant, real-world contexts and results in significant learning outcomes.

\section{Acknowledgments}

This work was fully funded by DIPA Universitas Pendidikan Indonesia No. DIPA 023.04.2.189747/2014.

\section{References}

[1] E. Komariah, "Jabar BKKBN," 2011. [Online]. Available: http://jabar.bkkbn.go.id. [Accessed 19 Februari 2014].

[2] M. o. N. Education, Jakarta, 2006.

[3] P. Ryan, "The future of vocational education and training," in Apprenticeship: between theory and practice, school and workplace. In: Pilz, M. (ed.), Springer, 2012, pp. 402-432.

[4] S. Wolter and P. Ryan, "Apprenticeship. In: Hanushek, E.A. et al. (eds)," in Handbook of the economics of education, Amsterdam, Nort Holland, 2011, pp. 521-576.

[5] R. Eskrootchi and G. oskrochi, "A Study of the Efficacy of Projectbased Learning Integrated with Computer-based Simulation STELLA," Educational Technology \& Society, vol. 13, no. 1, pp. 236$245,2010$.

[6] J. Thomas, "A review of research on project-based learning," The Autodesk Foundation, California, 2000.

[7] N. Hosseinzadeh and M. Hesamzadeh, "Application on PBL to reaching of electrical power system engineering," IEEE Transsactions on Education, vol. 55, no. 4, pp. 495-501, 2012.

[8] G. X.-L. Tai and M. C. Yuen, "Authentic assessment strategies in PBL," Proc. ASCILITE, pp. 983-993, 2007.

[9] Phoenix Contact, "PC Worx IEC 61131-programming," Phoenix Contact Gmbh \& Co KG, Munich, 2008.

[10] "PLCopen," PLC open, 1993. [Online]. Available: 